\title{
Corneal Endothelial Changes by Specular Microscopy after Uncomplicated Phaco-Emulsification of Hard Senile Cataract Graded by Pentacam
}

Adel Abdelrahman Osman, Sayed Mostafa El-Sayed, Amr Ehab Fahmy*

Department of Ophthalmology, Faculty of Medicine, Al-Azhar University, Cairo, Egypt

Corresponding author: Amr Ehab Fahmy, Mobile: (+20)01141237382,

E-mail: amrehabfahmy@gmail.com

\begin{abstract}
Background: Cataract is the most prevalent ophthalmic cause of reversible blindness and it is one of the primary concerns of the public health perspective surgery which is the primary and only treatment method known.

Objective: Assessment of corneal endothelial changes by using specular microscopy, after uncomplicated phacoemulsification in moderately hard nuclear 3 senile cataract.

Patients and Methods: The present study was performed on 30 eyes of 30 individuals preoperative assessed by pentacam to detect grade 3 nuclear cataract to be selected in our study, then corneal endothelium assessed by specular microscopy to evaluate the corneal endothelium to be reference and to be compared to $1^{\text {st }}$ and $3^{\text {rd }}$ month.

Results: A highly significant decrease in ECD $1^{\text {st }}$ month post-operative and a significant decrease in ECD $3^{\text {rd }}$ month in relation to pre-operative state. Highly significant increase in the coefficient of variation $1^{\text {st }}$ month postoperative and non-significant increase in the $3^{\text {rd }}$ month in relation to preoperative state. Highly significant decrease in the percentage of hexagonality $1^{\text {st }}$ month and $3^{\text {rd }}$ month post operatively. There is a highly significant reciprocal correlation between age and pre-operative endothelial cell density. $3^{\text {rd }}$ month post-operative decrease in ECD is significant correlated to male sex.

Conclusion: A major finding of our manuscript is that the harder the senile cataract the more time and surgical manipulation was done in spite of the same surgeon and the same operative condition lead to more endothelium lost and the more variation between the cells and decrease in the percentage of hexagonal post-operative.

Keywords: Corneal Endothelial, Specular Microscopy, Uncomplicated Phaco-Emulsification, Senile Cataract Graded by Pentacam.
\end{abstract}

\section{INTRODUCTION}

Age-related cataract, is not a rare disease even in those who are middle aged, approximately $17.5 \%$ of persons 43 to 54 years of age had some evidence of lens opacity ${ }^{(1)}$.

Cataract extraction by phacoemulsification is the most frequently performed ophthalmic surgery around the world, in which an ultrasonic device vibrating at a very high speed is inserted into the eye through a very small corneal incision, and today it focuses on rapid visual rehabilitation after surgery ${ }^{(2)}$.

Ultrasonic phacoemulsification offers several advantages, including a small incision and rapid postoperative visual recovery, and has become the preferred treatment for cataract ${ }^{(3)}$.

The remaining endothelium which cover the posterior corneal surface after injury is maintained by a gradual increase in the size of the remaining cells, which result in increased cellular pleomorphism and a decrease in the percentage of hexagonal cells ${ }^{(4)}$.

Corneal decompensation after phacoemulsification in the immediate postoperative period is a serious complication postoperatively and often leads to patient dissatisfaction and worsening the visual outcome ${ }^{(5)}$.

Endothelial injury may occur during cataract surgery due to a number of factors, such as corneal distortion, emulsifying of nuclear fragments, intraocular lens (IOL) contact, and release of free radicals ${ }^{(6)}$. Protection of corneal endothelium during cataract surgery is critical for achieving good visual outcomes. Maintenance of corneal clarity relies heavily upon the functionality of healthy endothelial

cells and an intact pumping system designed to remove fluid from the corneal stroma. It is well known that some degree of endothelial cell loss will be present after any cataract surgery ${ }^{(7)}$.

Endothelial cell loss after cataract surgery is an inevitable consequence of the procedure. Nonetheless, important steps taken during cataract surgery and the perioperative period may influence the rate of endothelial cell loss and thus potentially improve the visual outcome of this common surgical intervention. Proper patient selection and education, meticulous surgical technique, and good postoperative care are important for maintaining a clear cornea with excellent visual potential (7). Senile opacification of the crystalline lens is a commonly observed age-related phenomenon. Due to its high prevalence, cataract surgery is the most frequently performed surgical procedure worldwide. The most common used method for cataract grading is Lens Opacities Classification System III (LOCS III) (8).

An established disadvantage of the old methods using clinical parameters is the subjective nature for the grading process as the case of use of LOCS III as a grading method and similar methods, there are multiple discrepancies in routine performance. For example, slitlamp settings and the evaluator's expertise can play a role ${ }^{(9)}$.

Pentacam nucleus staging based on the Scheimpflug principle that state that, the plane of the 
pentacam camera take multiple images of the optical section through the lens, from that images can perform a 3D lens diagram and densitometry of the nuclear opacity, and also can ignore the degree of scattering that affect image quality. Allowing more discreet fine levels of opacities progression to be identified ${ }^{(9)}$.

Cataract surgery requires a fine objective preoperative patient evaluation, for corneal endothelium with respect to the assessment of nuclear hardness, and tailoring the best surgical techniques mandatory to achieve the maximum postoperative visual outcome quality and the least stress on the endothelium to decrease such vision threatening complication ${ }^{(\mathbf{1 0})}$.

\section{AIM OF THE WORK}

Assessment of corneal endothelial changes by using specular microscopy, after uncomplicated phacoemulsification in moderately hard nuclear 3 senile cataract.

\section{PATIENTS AND METHODS}

This is descriptive prospective study that assessed the influence of uneventful phacoemulsification on the corneal endothelium one and three months post-operative in 30 Eyes by konan specular microscopy in moderately hard N3 cataract graded by oculus pentacam nucleus staging (PNS) for patients attending the specialist eye hospital at the Military Medical Complex of Kobri El Kobba, Cairo, Egypt.

A total of 30 eyes of 30 patients were enrolled in our study of both gender with age-related nuclear cataracts without previous history of ocular surgery, diagnosed between December 2018 and April 2019. A thorough assessment was performed on each patient prior to surgery.

\section{Ethical approval and written informed consent:} An approval of the study was obtained from Al-Azhar University academic and ethical committee. Every patient signed an informed written consent for acceptance of the operation.

\section{The assessment included:}

1. Complain including onset, course and duration.

2. Past medical history to exclude presence of the diseases that affect the study.

3. Past ocular history that exclude all previous ocular surgery and diseases.

4. Macular function test and color discrimination.

5. Pupillary light reflex, direct and consensual.

6. Corrected and uncorrected distance visual acuity.

7. Slit-lamp assessment and cataract grading according to LOCS 3.

8. Fundoscopy to rule out posterior segment pathology affecting the anterior segment.

9. Scheimpflug imaging by using oculus pentacam

10. Specular microscopy, the same surgeon carried out the cataract surgery, using the same procedure, a $2.2 \mathrm{~mm}$ temporal clear corneal incision under the effect of local anesthesia with a stop and chop method to halve the nucleus.

\section{Inclusion criteria}

\section{Key inclusion criteria included:}

1. Patient complaining of diminution of vision of gradual onset and progressive course.

2. Adult patients from 50 to 70 years of age

3. Both gender with no prior ocular disease.

4. Crystalline clear cornea devoided from any corneal dystrophy and degenerations.

5. Moderately hard senile cataract grade 3 according to pentacam nucleus staging (PNS).

6. Undergoing routine phacoemulsification surgery using horizontal

7. Corneal endothelial cell density more than $\mathbf{1 5 0 0}$ cell $/ \mathrm{mm}$.

\section{Exclusion criteria}

\section{Systemic exclusion criteria}

We excluded patients with evidence of proliferative diabetic retinopathy (T2DM group) characterized by the occurrence of vitreous hemorrhage or tractional retinal detachment.

\section{Local eye disease and previous surgery}

1) Preoperative endothelial count less than 1500 cells $/ \mathrm{mm}$.

2) Any type of corneal pathology as corneal degeneration and corneal dystrophy.

3) Contact lens wear history.

4) Ocular trauma or surgery.

5) Current use of any kind of ocular treatment other than eye lubricant.

6) Patients with conditions that would prevent evaluation of the cornea by specular microscopy.

\section{Ocular examination and investigation:}

All the subjects had a comprehensive ocular examination including:

1. Visual acuity by Snellen chart including uncorrected visual acuity and the best corrected.

2. Color vision by Ichihara charts.

3. Amsler grid to assess the macular function

4. Slit-lamp examination of the anterior segment.

5. Dilate the patient with 3 drops of Cyclopentolate then grading the cataract according to LOCS 3.

6. Fundus examination to exclude any retinal disease.

\section{Investigation performed:}

The specular microscopy examination was performed before surgery, at the $1^{\text {st }}$ and $3^{\text {rd }}$ month follow-up visits after the phacoemulsification procedure.

Specular microscopy used in this study is SP50000 model CC-5000 specular noncontact (cellcheck konan medical INC), for assessment of the corneal endothelium cell density, 6A percentage of hexagonality, C.V coefficient of variation.

The endothelial cell density (cells $/ \mathrm{mm} 2$ ) was calculated by analyzing not less than 30 cells of the 
central cornea before surgery, one month and three months after, specular microscopy (konan noncon specular microscope cc-5000) was performed three times. In both situations, the highest endothelial cell count has been chosen.

In addition, coefficient of variation $(\mathrm{CoV})$ and percentage of polymegathism were obtained. Three repeated measurements obtained by the same physician (by me).

Pentacam HR type 70900 SN 98129080 and scheimpflug imaging was done before surgery and select moderately hard senile cataract grade 3 according to PNS for densitometry.

Two measurements were collected per eye using the Scheimpflug system. This process was applied to evaluate lens density prior to surgery provided by the 3-D image of the anterior segment.

\section{Surgical technique}

All the cases have been done using the endocapsular phaco technique, and the mechanical breakdown of the nucleus also done inside the bag whenever is needed.

An INFINITI phacoemulsification apparatus (ALCON) implementing the Elliptical cutting pattern was used for phacoemulsification in the capsular bag.

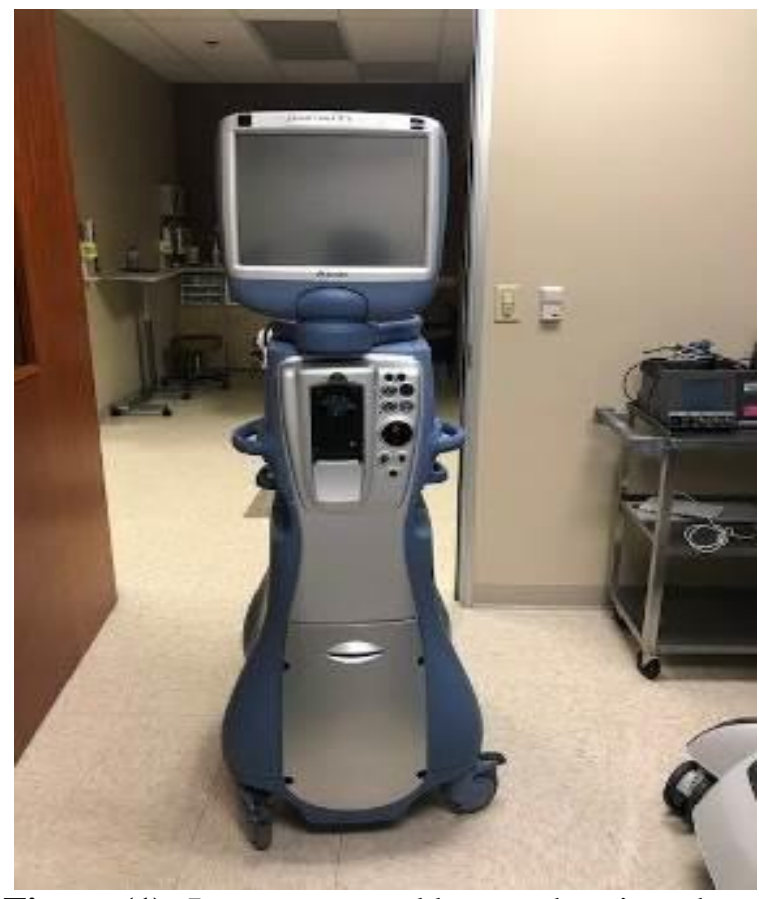

Figure (1): Image captured by me showing phaco machine used in the study.

All the intraoperative phaco parameters are fixed for all the patients. All patients underwent phacoemulsification surgery with an in-the-bag singlepiece intraocular lens implant, without complications.

All eyes were dilated using 3 drops of Cyclopentolate and Phenylephrine with $10 \mathrm{~min}$ interval between each drop $1 \mathrm{~h}$ before the surgical procedure.The same surgeon performed all the surgical procedures employing the Infiniti Vision System and a 0.9-mm ABS Mini-Flared 45 Kelman tip (Novartis Laboratories, Basel, Switzerland).

In addition, a standard technique of horizontal phaco-chop under local anesthesia was performed, using retrobulbar anesthesia prepaered by mixing $4 \mathrm{ml}$ xylocaine with $4 \mathrm{ml}$ lidocane with hyalase.

A $2.4 \mathrm{~mm}$ clear corneal incisions and manually created capsulorhexies from 5.0 to $5.5 \mathrm{~mm}$ were performed for all surgeries, using the same ophthalmic visco surgical device (OVD) easyvisc $2.4 \%$ hydroxyl propylmethyl cellulose and easy luron $1.6 \%$ sodium hyalournte.

\section{Phaco parameters used in the study:}

\section{1) Sculpture}

Irrigation $110 \mathrm{~cm} \mathrm{H} 2 \mathrm{O}$ - phacopower 0 torsional amplitude 100 limit - vacuum 75 limit aspiration rate 35 limit.

\section{2) Chop}

Irrigation $110 \mathrm{~cm} \mathrm{H} 2 \mathrm{O}$ - phacopower $0-$ torsional amplitude 100 limit - vacuum 400 limit aspiration rate 35 limit.

\section{3) Quadrant removal}

Irrigation $110 \mathrm{~cm} \mathrm{H} 2 \mathrm{O}$ - phacopower 0 -torsional amplitude 90 - vacuum 350 - aspiration rate 35 .

\section{4) Epinucleus}

Irrigation $110 \mathrm{~cm} \mathrm{H} 2 \mathrm{O}$ - phacopower 0 -torsional amplitude 15 - vacuum 400 - aspiration rate 32 .

5) Cortex

Vacuum 450 - aspiration rate 30.

After cataract removal and aspiration of cortical material, the appropriate IOL was implanted in the capsular bag and the procedure was concluded.

Finally, all patients received combined tobramycin/ dexamethasone eye drops every $2 \mathrm{~h}$ at the first week, as postoperative treatment, then patching.

\section{Ethical consideration}

- All patients received complete explanation of the nature and the purpose of the study.

- An informed consent was obtained from all participants in the research before inclusion.

- $\quad$ All names of the participants were hidden and replaced by numbers to maintain their privacy and confidentiality of the data.

Data were not used for any other purpose.

\section{Follow up}

Following up the patients by slit lamp examination for corneal clarity, anterior chamber formation, IOL in its original place and for any reaction post operatively and specular microscopy for cell density and morphology, $1^{\text {st }}$ and $3^{\text {rd }}$ months postoperative intervals follow up.

\section{Statistical analysis}

Data were collected, revised, coded and entered to the Statistical Package for Social Science 
(IBM SPSS) version 23. The quantitative data were presented as mean, standard deviations and ranges when their distribution found parametric.

Also, qualitative variables were presented as number and percentages.

The comparison between two independent groups with quantitative data and parametric distribution were done by using Independent t-test; the comparison between more than two paired groups with quantitative data and parametric distribution were done by using repeated measure ANOVA test.

Spearman correlation coefficients were used to assess the correlation between two quantitative parameters in the same group.

The confidence interval was set to $95 \%$ and the margin of error accepted was set to $5 \%$. So, the pvalue was considered significant as the following:

- P-value >0.05: Non-significant (NS)

- P-value <0.05: Significant $(\mathrm{S})$
- P-value < 0.01: Highly significant (HS)

\section{RESULTS}

1) Age

The age distributions range: $51-70$ years with Mean $\pm \mathrm{SD}(64.40 \pm 5.47)$.

\section{2) Gender}

Thirty patients included in this study $11(36.7 \%)$ were females and $19(63.3 \%)$ were male patients.

Table (1): Age and gender distribution

\begin{tabular}{|c|c|c|}
\hline \multicolumn{2}{|c|}{ No. $=30$} \\
\hline \multirow{2}{*}{ Sex } & Females & $11(36.7 \%)$ \\
& Males & $19(63.3 \%)$ \\
\hline \multirow{2}{*}{ Age } & $\begin{array}{c}\text { Mean } \pm \text { SD } \\
\text { Range }\end{array}$ & $\begin{array}{c}64.40 \pm 5.47 \\
51-70\end{array}$ \\
\hline
\end{tabular}

The table show that $63.3 \%$ were males and $36.7 \%$ were females.

Table (2): Progressive changes in endothelial cell density

\begin{tabular}{|c|c|c|c|c|c|c|}
\hline \multirow{2}{*}{ Endothelial cell density } & Preoperative & \multirow{2}{*}{\begin{tabular}{|c|}
$\begin{array}{c}1 \text { month } \\
\text { post-operative }\end{array}$ \\
No. $=30$ \\
\end{tabular}} & $\begin{array}{c}3 \text { months } \\
\text { post-operative }\end{array}$ & \multirow{2}{*}{$\begin{array}{l}\text { Test } \\
\text { value• }\end{array}$} & \multirow[t]{2}{*}{ P-value } & \multirow[t]{2}{*}{ pig. } \\
\hline & No. $=30$ & & No. $=30$ & & & \\
\hline $\begin{array}{l}\text { Mean } \pm \text { SD } \\
\text { Range }\end{array}$ & \begin{tabular}{|c|}
$2542.20 \pm 285.18$ \\
$1866-3268$
\end{tabular} & $\begin{array}{c}2118.90 \pm 348.81 \\
1351-2801\end{array}$ & \begin{tabular}{|c|}
$2023.10 \pm 390.38$ \\
$1331-2793$
\end{tabular} & 56.576 & 0.000 & HS \\
\hline \multicolumn{7}{|c|}{ Post Hoc analysis by Bonferroni } \\
\hline \multicolumn{2}{|l|}{$\mathbf{P 1}$} & \multicolumn{2}{|l|}{$\mathbf{P 2}$} & \multicolumn{2}{|l|}{$\mathbf{P 3}$} & \\
\hline 0.000 & & \multicolumn{2}{|l|}{0.000} & \multicolumn{2}{|l|}{0.010} & \\
\hline
\end{tabular}

P-value >0.05: Non significant (NS); P-value <0.05: Significant (S); P-value< 0.01: highly significant (HS)

$\because$ Repeated measure ANOVA test

P1: Pre-operative Vs. 1 month, P2: Pre-operative Vs. 3 months,

P3: 1 month Vs. 3 months

Table (2) show progressive changes of endothelial cell density using post hoc analysis by bonferroni as the 30 patients pre-operative ECD ranging (1866 - 3268) with Mean \pm SD $(2542.20 \pm 285.18)$ show highly significant decrease in ECD 1 month post-operative ranging (1351 - 2801) with Mean \pm SD $(2118.90 \pm 348.81)$.

$3^{\text {rd }}$ month post-operative ECD range $(1331-2793)$ with Mean \pm SD $(2023.10 \pm 390.38)$ show highly significant decrease in ECD in relation to pre-operative. $3^{\text {rd }}$ month post-operative ECD show significant decrease in ECD in relation to $1^{\text {st }}$ month ECD postoperative.

Table (3): Changes of coefficient of variation following cataract surgery

\begin{tabular}{|c|c|c|c|c|c|c|}
\hline \multirow{2}{*}{$\begin{array}{c}\text { Coefficient } \\
\text { of variation }\end{array}$} & Preoperative & \multirow{2}{*}{$\begin{array}{c}\begin{array}{c}1 \text { month } \\
\text { post-operative }\end{array} \\
\text { No. }=30 \\
\end{array}$} & $\begin{array}{c}3 \text { months } \\
\text { post-operative }\end{array}$ & \multirow{2}{*}{$\begin{array}{l}\text { Test } \\
\text { value• }\end{array}$} & \multirow[t]{2}{*}{ P-value } & \multirow[t]{2}{*}{ ig. } \\
\hline & No. $=30$ & & No. $=30$ & & & \\
\hline $\begin{array}{c}\text { Mean } \pm \text { SD } \\
\text { Range }\end{array}$ & $\begin{array}{c}44.53 \pm 6.58 \\
33-56 \\
\end{array}$ & $\begin{array}{c}52.20 \pm 8.07 \\
38-73 \\
\end{array}$ & $\begin{array}{c}51.67 \pm 8.71 \\
33-73 \\
\end{array}$ & 21.941 & 0.000 & IS \\
\hline \multicolumn{7}{|c|}{ Post Hoc analysis by Bonferroni } \\
\hline P1 & & P2 & & P3 & & \\
\hline 0.000 & & 0.000 & & 1.000 & & \\
\hline
\end{tabular}

P-value >0.05: Non significant (NS); P-value <0.05: Significant (S); P-value< 0.01: highly significant (HS)

$\bullet:$ Repeated measure ANOVA test

Pre-operative CV ranging (33 - 56) with Mean \pm SD $(44.53 \pm 6.58)$ show highly significant increase in CV $1^{\text {st }}$ month post-operative

$3^{\text {rd }}$ month post-operative show highly significant increase in CV in relation to pre-operative.

$3^{\text {rd }}$ month post-operative show insignificant increase in $\mathrm{CV}$ in relation to $1^{\text {st }}$ month post-operative. 
Table (4): Percentage of hexagonality 6A

\begin{tabular}{|c|c|c|c|c|c|c|}
\hline \multirow{2}{*}{$\begin{array}{c}\text { Percentage of } \\
\text { hexagonally }(6 \mathrm{~A})\end{array}$} & Preoperative & $\begin{array}{c}1 \text { month } \\
\text { post-operative }\end{array}$ & $\begin{array}{c}3 \text { months } \\
\text { post-operative }\end{array}$ & \multirow{2}{*}{$\begin{array}{c}\text { Test } \\
\text { value• }\end{array}$} & \multirow[t]{2}{*}{ P-value } & \multirow[t]{2}{*}{ ig. } \\
\hline & No. $=30$ & No. $=30$ & No. $=30$ & & & \\
\hline $\begin{array}{c}\text { Mean } \pm \mathrm{SD} \\
\text { Range }\end{array}$ & $\begin{array}{c}48.73 \pm 9.35 \\
23-69\end{array}$ & $\begin{array}{c}40.90 \pm 7.01 \\
27-59\end{array}$ & $\begin{array}{c}38.07 \pm 6.87 \\
25-50\end{array}$ & 49.351 & 0.000 & IS \\
\hline \multicolumn{7}{|c|}{ Post Hoc analysis by Bonferroni } \\
\hline \multicolumn{2}{|l|}{ P1 } & \multicolumn{2}{|l|}{$\mathbf{P 2}$} & \multicolumn{2}{|l|}{$\mathbf{P 3}$} & \\
\hline 0.000 & & 0.000 & & \multicolumn{2}{|l|}{0.007} & \\
\hline
\end{tabular}

P-value >0.05: Non significant (NS); P-value <0.05: Significant (S); P-value< 0.01: highly significant (HS)

$\because$ Repeated measure ANOVA test

The relation between preoperative, 1 st, 3 rd months post-operative show highly significant changes.

Pre-operative percentage of hexagonality range (23-69) with Mean \pm SD (48.73 \pm 9.35$)$ show highly significant decrease in $1^{\text {st }}$ and $3^{\text {rd }}$ months post-operative in relation to preoperative $6 \mathrm{~A}$.

Table (5): The relation between age and ECD, CV, 6A

\begin{tabular}{|c|c|c|c|}
\hline \multirow{2}{*}{} & & \multicolumn{2}{|c|}{ Age } \\
\cline { 3 - 4 } & & $\mathbf{r}$ & P-value \\
\hline \multirow{2}{*}{$\begin{array}{c}\text { Endothelial cell } \\
\text { density }\end{array}$} & Preoperative & $\mathbf{- 0 . 3 8 1 ^ { * }}$ & $\mathbf{0 . 0 3 8}$ \\
\cline { 2 - 4 } & One-month post-operative & -0.074 & 0.699 \\
\cline { 2 - 4 } & Three months post-operative & -0.080 & 0.674 \\
\hline $\begin{array}{c}\text { Coefficient of } \\
\text { variation }\end{array}$ & Preoperative & 0.014 & 0.942 \\
\cline { 2 - 4 } & One-month post-operative & -0.113 & 0.553 \\
\cline { 2 - 4 } & Three months post-operative & -0.273 & 0.144 \\
\hline \multirow{2}{*}{$\begin{array}{c}\text { Percentage of } \\
\text { hexagonality } \\
(\mathbf{6 A})\end{array}$} & Preoperative & 0.125 & 0.509 \\
\cline { 2 - 4 } & One- month post-operative & 0.059 & 0.758 \\
\cline { 2 - 4 } & Three months post-operative & 0.192 & 0.310 \\
\hline
\end{tabular}

This table presents that there is an only significant reciprocal correlation between the age and the preoperative ECD ( $\mathrm{r}$ stand for the relation).

Table (6): Show significant correlation between gender and ECD at $3^{\text {rd }}$ month post-operative follow up visit interval and non-significant correlation for C.V and 6A for gender at any post-operative visit

Table (6): Correlation between gender and ECD

\begin{tabular}{|c|c|c|c|c|c|c|c|}
\hline & & & Females & Males & \multirow{2}{*}{$\begin{array}{c}\text { Test } \\
\text { value }\end{array}$} & \multirow{2}{*}{ P-value } & \multirow{2}{*}{ Sig. } \\
\hline & & & No. $=11$ & No. $=19$ & & & \\
\hline \multirow[t]{3}{*}{$\begin{array}{l}\text { Endothelial } \\
\text { cell density }\end{array}$} & Preoperative & $\begin{array}{l}\text { Mean } \pm \text { SD } \\
\text { Range }\end{array}$ & $\begin{array}{c}2634.00 \pm 252.03 \\
2096-2950\end{array}$ & $\begin{array}{c}2489.05 \pm 295.99 \\
1866-3268\end{array}$ & 1.361 & 0.184 & NS \\
\hline & $\begin{array}{l}\text { First- month } \\
\text { post-operative }\end{array}$ & $\begin{array}{c}\text { Mean } \pm \text { SD } \\
\text { Range }\end{array}$ & $\begin{array}{c}2255.09 \pm 305.50 \\
1724-2801\end{array}$ & $\begin{array}{c}2040.05 \pm 355.35 \\
1351-2582 \\
\end{array}$ & 1.677 & 0.105 & NS \\
\hline & $\begin{array}{l}\text { Three months } \\
\text { post-operative }\end{array}$ & $\begin{array}{c}\text { Mean } \pm \text { SD } \\
\text { Range }\end{array}$ & $\begin{array}{c}210.82 \pm 301.57 \\
1704-2793\end{array}$ & $\begin{array}{c}1914.42 \pm 401.25 \\
1331-2564 \\
\end{array}$ & 2.122 & 0.043 & $\mathrm{~S}$ \\
\hline \multirow[t]{3}{*}{$\begin{array}{c}\text { Coefficient of } \\
\text { variation }\end{array}$} & Preoperative & $\begin{array}{c}\text { Mean } \pm \mathrm{SD} \\
\text { Range }\end{array}$ & $\begin{array}{c}44.55 \pm 6.01 \\
33-52\end{array}$ & $\begin{array}{c}44.53 \pm 7.05 \\
33-56\end{array}$ & 0.008 & 0.994 & NS \\
\hline & $\begin{array}{l}\text { First-month } \\
\text { post-operative }\end{array}$ & $\begin{array}{c}\text { Mean } \pm \text { SD } \\
\text { Range }\end{array}$ & $\begin{array}{c}51.73 \pm 7.88 \\
39-66 \\
\end{array}$ & $\begin{array}{c}52.47 \pm 8.38 \\
38-73 \\
\end{array}$ & -0.240 & 0.812 & NS \\
\hline & $\begin{array}{l}\text { Three months } \\
\text { post-operative }\end{array}$ & $\begin{array}{c}\text { Mean } \pm \text { SD } \\
\text { Range }\end{array}$ & $\begin{array}{c}50.64 \pm 8.55 \\
33-61 \\
\end{array}$ & $\begin{array}{c}52.26 \pm 8.98 \\
37-73 \\
\end{array}$ & -0.486 & 0.630 & NS \\
\hline \multirow{3}{*}{$\begin{array}{l}\text { percentage of } \\
\text { hexagonality } \\
\quad(6 A)\end{array}$} & Preoperative & $\begin{array}{c}\text { Mean } \pm \text { SD } \\
\text { Range }\end{array}$ & $\begin{array}{c}51.55 \pm 8.69 \\
40-69\end{array}$ & $\begin{array}{c}47.11 \pm 9.55 \\
23-67\end{array}$ & 1.267 & 0.216 & NS \\
\hline & $\begin{array}{l}\text { First month } \\
\text { post-operative }\end{array}$ & $\begin{array}{c}\text { Mean } \pm \text { SD } \\
\text { Range }\end{array}$ & $\begin{array}{c}43.09 \pm 7.57 \\
33-59 \\
\end{array}$ & $\begin{array}{c}39.63 \pm 6.53 \\
27-54 \\
\end{array}$ & 1.319 & 0.198 & NS \\
\hline & $\begin{array}{l}\text { Three months } \\
\text { post-operative }\end{array}$ & $\begin{array}{c}\text { Mean } \pm \text { SD } \\
\text { Range }\end{array}$ & $\begin{array}{c}38.27 \pm 6.84 \\
30-50\end{array}$ & $\begin{array}{c}37.95 \pm 7.07 \\
25-50\end{array}$ & 0.123 & 0.903 & NS \\
\hline
\end{tabular}


ejhm.journals.ekb.eg

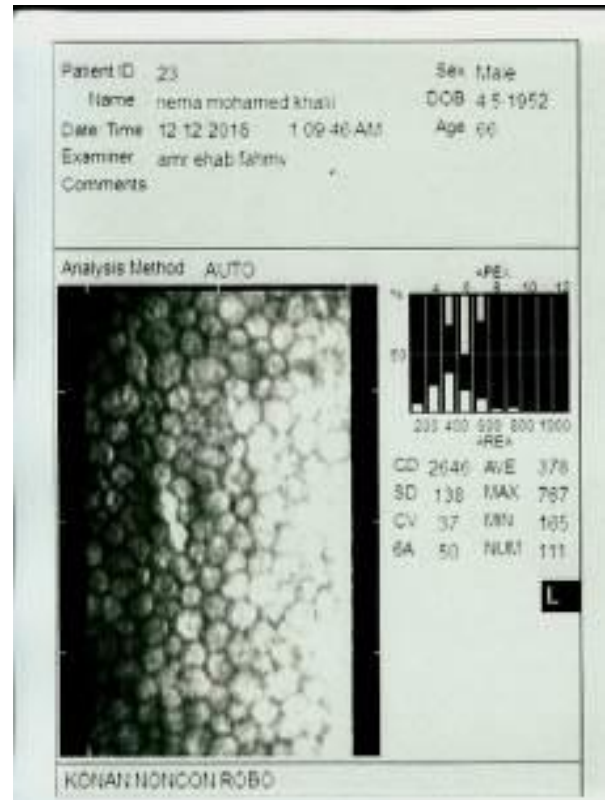

Figure (2): One of the study cases preoperatively showing CD2646 CV37 6A50.

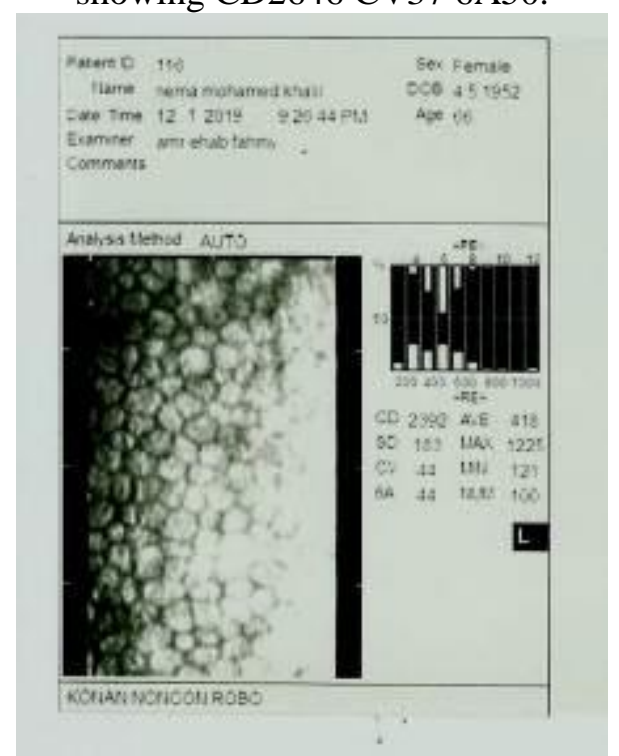

Figure (3): One-month post-operative show endothelial cell loss showing CD2392 CV44 6A44.

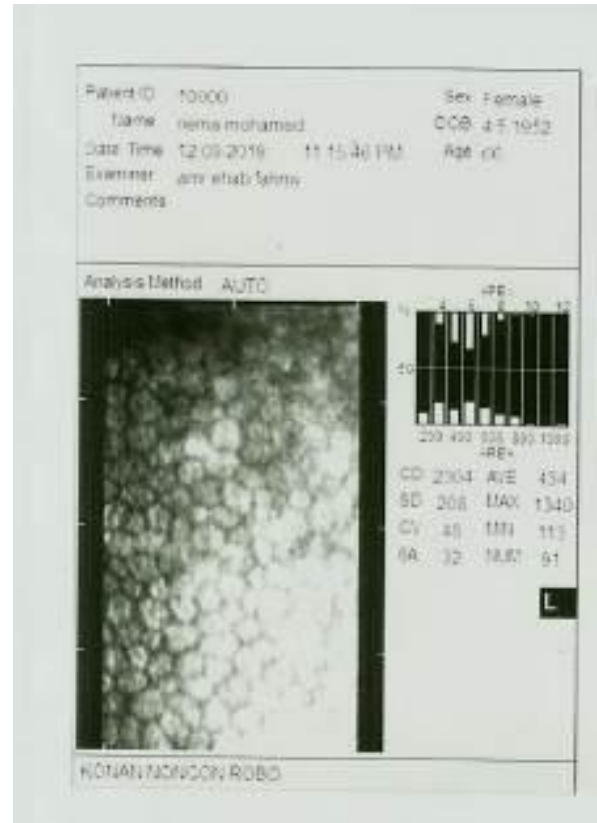

Figure (4): Three months post-operative showing CD2304 CV48 6A32.

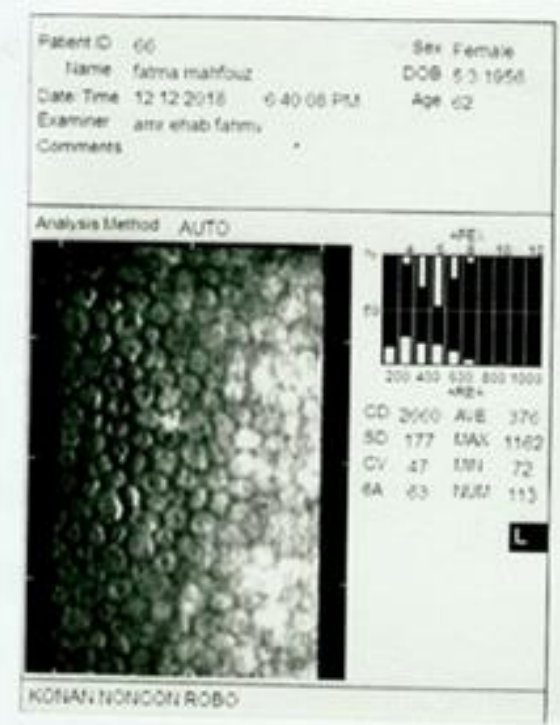

Figure (5): Preoperative CD2660 CV47 6A63.

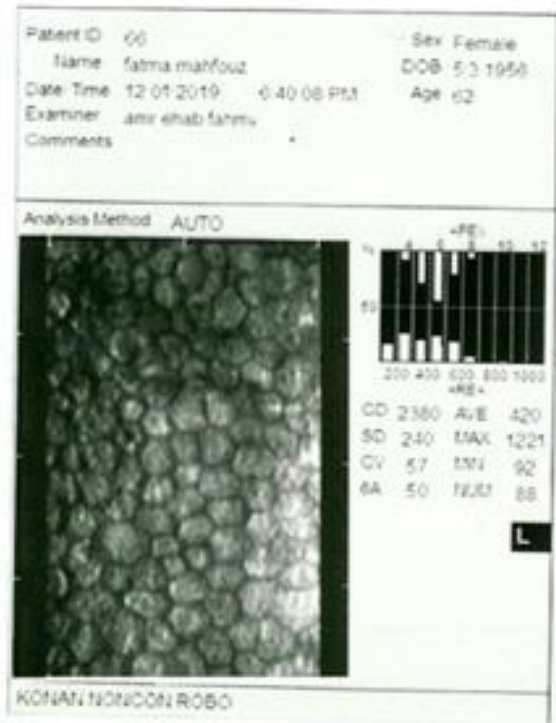


Figure (6): $1^{\text {st }}$ month postoperative CD2380 CV57 6 A50.

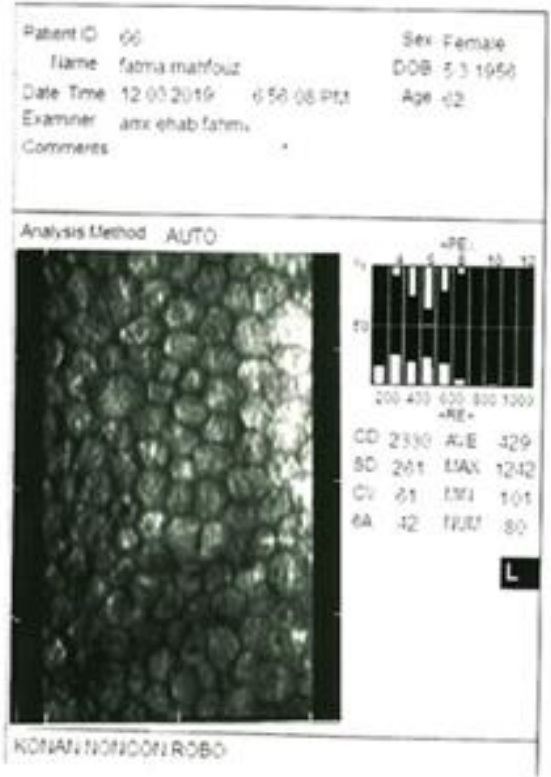

Figure (7): $3^{\text {rd }}$ month postoperative. CD2330 CV61 $6 \mathrm{~A} 42$.

\section{DISCUSSION}

The present study is the first one to evaluate the effects of phacoemulsification on corneal endothelial cell count based on grading the degree of cataract by using pentacam nucleus staging in an Egyptian population.

\section{Follow up time interval}

Although there is a controversy exists over the length of time required for the endothelial cell count to stabilize post-operatively. The majority of other studies have evaluated endothelial cell loss over a relatively short term period of 1 month and long term period 3 months ${ }^{(11)}$.

We decided to follow up the endothelial loss in the first month and the third month post-operative which is consistent with Fernández-Muñoz et al. ${ }^{\text {(2) }}$ study that followed up the endothelial loss in the same time interval post-operatively which revealed significant decrease in endothelial cells in both the short term and long term ${ }^{(2)}$.

Bourne et al. (11) support our study, reported that stabilization of cell density throughout the cornea after phacoemulsification by 3 months.

According to corneal changes after phacoemulsification corneal thickness returned nearly to baseline 1 month after surgery, while endothelial loss persisted, being compensated by the remaining endothelial cells ${ }^{(\mathbf{1 2})}$.

But Bourne et al. ${ }^{(11)}$ stands against the present study where they reported that the endothelial cell density continues to decrease beyond 3 months, yet the rate of loss lessens with time which make it one of the pitfalls of the study.

\section{Grading nuclear density by PNS}

This study is characterized by grading the nuclear density on a new objective method for grading (PNS) away from the old subjective methods of cataract grading (LOCS 3 ) that's depending on the color of the nucleus and the examiner experience.

Kim et al. ${ }^{(13)}$ used pentacam nucleus staging for cataract grading which is consistent with the present work but their finding is different to my study where they correlated it to torsional amplitude, phacoemulsification time, and cumulated dissipated energy to get the best surgical outcome and the least endothelial cell loss but we fixed all the phaco parameters so we recommend the correlation of the cataract grading by PNS to the torsional power in next studies.

Nixon ${ }^{(14)}$ revealed a significant correlation between the pentacam nucleus grading system and effective phaco time after the phaco settings were adjusted to the nuclear cataract grade by PNS, especially in eyes with high grade cataract.

That's supporting the aim of the work of our study to adjust the phaco parameters according to the grade, not to fix it as we fixed, but we did that to reach the least loss of the endothelium but we fixed all the parameters to find the frank effect of US on the endothelium.

Another support for grading method used in my study, Pei et al. (15) agree that Pentacam Scheimpflug densitometry is a good objective clinical parameter for judging a patient's visual impairment resulting from light scattering caused by lens opacification.

\section{Endothelial cell loss}

The majority of studies agree that phacoemulsification results in qualitative and quantitative alterations at the corneal ECD ${ }^{(16)}$.

Tang et al. ${ }^{(17)}$ agree with my study that he found that patients have a significantly lower ECD at all post-operative time points in relation to preoperative state, eyes with moderately hard senile cataract patients are subjected to various changes due to cataract extraction procedure. Corneal endothelium has shown morphological and morphometric alterations manifested by pleomorphism and polymegathism, as well as a lower percentage of hexagonal cells, and that agree and support our results.

Our study revealed a value of $16.6 \%$ loss of endothelial cell density after phacoemulsification of grade 3 hard senile cataract $1^{\text {st }}$ month post-operative and that increase up to $3 \%$ till the $3^{\text {rd }}$ month postoperative.

Gonzalez-Salinas and coworkers ${ }^{(18)}$ agree with our results that there is a lower endothelial density by $12-14 \%$ in patients after 
phacoemulsification which support the results of our study ${ }^{(18)}$.

What stands also against our study Inoue and coworkers ${ }^{(19)}$ who studied the factors that predispose to endothelial cell count decrease following phacoemulsification. They found that the age factor is predisposing factor that affect the decrease in endothelial density after phacoemulsification, but our study revealed that age is only highly significant correlated to preoperative ECD without any relation to $1^{\text {st }}$ or $3^{\text {rd }}$ month post-operative.

In our study, highly significant decrease in mean ECD values between pre-surgical and postoperative ( $1^{\text {ST }}$ and $3^{\text {rd }}$ month follow-up visits) was evidenced within each group. There is high statistically significant increase in the coefficient of variation $1^{\text {st }}$ month in relation to preoperative and a non-statistically significant decrease post-operative $3^{\text {rd }}$ month in relation to $1^{\text {st }}$ month.

So, there is no statistically significant difference is found when comparing $\mathrm{CV}$ between $1^{\text {st }}$ and $3^{\text {rd }}$ month post-operatively.

Addition support to our study results, CalvoMaroto et al. ${ }^{(16)}$ said that it is important to follow up the significant differences evidenced on the $\mathrm{CV}$ in both in the pre-surgical and the post-operative follow-up visits since morphological changes have been observed in the corneal endothelium of the patients, These changes in cell density, percentage of cells, hexagonality, and variation coefficient.

The employment of horizontal phaco-chop technique has been widely assessed for cataract surgery, and several studies report no differences when compared to other phacoemulsification techniques; however, in a report by Park et al. ${ }^{\text {(20), }}$ the phaco-chop technique can be more effective for lens removal, with less corneal endothelial damage, than the divide-and conquer and stop-and-chop techniques in eyes with hard cataract having coaxial phacoemulsification surgery, which support the usage of this technique in our study to detect the least endothelial cell loss.

Demircan et al. ${ }^{(21)}$ evaluated the relationship between the lens density based on pentacam nucleus staging software and level of ultrasound energy during phacoemulsification. Significant linear correlations have been noticed between pentacam nucleus densitometry and total ultrasound time and cumulated dissipated energy. Strong positive correlations were observed in our study between the phacodynamic parameters and the degree of endothelial cells loss following the surgery. With the hardness of the nucleus, more phacoemulsification energy and time were mandated for hard nucleus removal in the phacodynamics context, so we recommend in the next studies to be done in this topic, to correlate te PNS grading to the phaco parameters used to reach the least endothelial cell loss.

\section{CONCLUSION}

In conclusion, despite healthy cornea and without previous surgical history and no corneal abnormalities before surgery, there is marked endothelial loss by phacoemulsification. This is particularly important in patients especially with harder nuclear density, so we recommend after this study the necessity to adjust the phaco parameters according to pentacam nucleus staging to reach the least endothelial cell loss and refine the current surgical methods and instruments to minimize the endothelial damage.

A major finding of our manuscript is that the harder the senile cataract the more time and surgical manipulation was done in spite of the same surgeon and the same operative condition lead to more endothelium lost and the more variation between the cells and decrease in the percentage of hexagonal post-operative.

\section{Recommendations}

It is recommended that a detailed assessment of endothelial cell count preoperatively and according to it specific phacoemulsificationtechnique used and phaco parameters and phaco dynmics used on patients adjusted for the degree of nuclear density which is essential to accurately evaluate the influence of surgical technique on patients' outcome and that was done in my study.

\section{REFERENCES}

1. Klein BE, Klein R, Lee KE (2002): Incidence of agerelated cataract over a 10-year interval: The Beaver Dam Eye Study. Ophthalmology, 109(11): 2052-7.

2. Fernández-Muñoz E, Zamora-Ortiz R, GonzalezSalinas R (2018): Endothelial cell density changes in diabetic and nondiabetic eyes undergoing phacoemulsification employing phaco-chop technique. International Ophthalmology, 8:1-7.

3. Chen G, Wang D, Du Y, Huang $H$ (2015): Effect of continuous ultrasonic phacoemulsification with anterior chamber maintainer on corneal endothelial damage in hard nuclear cataract. European Journal of Ophthalmology, 25(3): 198-201.

4. Abdellah MM, Ammar HG, Anbar M, Mostafa EM, Farouk MM, Sayed K, Alsmman AH, Elghobaier MG (2019): Corneal endothelial cell density and morphology in healthy Egyptian eyes. https://www.hindawi.com/journals/joph/2019/6370241/

5. Sharma N, Deepali S, Sreelakshmi P, Pranita N, Sreeshankar S, Prafullakumar M (2017): Corneal edema after phacoemulsification. Indian Journal of Ophthalmology, 65(12): 1381.

6. Cameron MD, Poyer JF, Aust SD (2001): Identification of free radicals produced during phacoemulsification. Journal of Cataract \& Refractive Surgery, 27(3): 463-70. 
7. Rosado-Adames N, Afshari NA (2012): The changing fate of the corneal endothelium in cataract surgery. Current Opinion in Ophthalmology, 23(1): 3-6.

8. Weiner X, Baumeister M, Kohnen T, Bühren J (2014): Repeatability of lens densitometry using Scheimpflug imaging. Journal of Cataract \& Refractive Surgery, 40(5): 756-63.

9. Al-Osaily AM, Al-Jindan MY (2018): Intracorrelations between cataract density based on Scheimpflug image, phacodynamics, surgery duration, and endothelial cell loss after phacoemulsification. Saudi Journal of Ophthalmology, 32(3): 188-93.

10. Hugod M, Storr-Paulsen A, Norregaard JC, Nicolini J, Larsen AB, Thulesen J (2011): Corneal endothelial cell changes associated with cataract surgery in patients with type 2 diabetes mellitus. Cornea, 30(7): 749-53.

11. Bourne RR, Minassian DC, Dart JK, Rosen P, Kaushal S, Wingate N (2004): Effect of cataract surgery on the corneal endothelium: modern phacoemulsification compared with extracapsular cataract surgery. Ophthalmology, 111(4): 679-85.

12. Fakhry MA, El Shazly MI (2011): Torsional ultrasound mode versus combined torsional and conventional ultrasound mode phacoemulsification for eyes with hard cataract. Clinical ophthalmology (Auckland, NZ), 5: 973-7.

13. Kim JS, Chung SH, Joo CK (2009): Clinical application of a Scheimpflug system for lens density measurements in phacoemulsification. Journal of Cataract \& Refractive Surgery, 35(7): 1204-9.

14. Nixon DR (2010): Preoperative cataract grading by Scheimpflug imaging and effect on operative fluidics and phacoemulsification energy. Journal of Cataract \& Refractive Surgery, 36(2): 242-6.
15. Pei X, Bao Y, Chen Y, Li X (2008): Correlation of lens density measured using the Pentacam Scheimpflug system with the Lens Opacities Classification System III grading score and visual acuity in age-related nuclear cataract. British Journal of Ophthalmology, 92(11): 1471-5.

16. Calvo-Maroto AM, Cerviño A, Perez-Cambrodí RJ, García-Lázaro S, Sanchis-Gimeno JA (2015): Quantitative corneal anatomy: evaluation of the effect of diabetes duration on the endothelial cell density and corneal thickness. Ophthalmic and Physiological Optics, 35(3): 293-8.

17. Tang $Y$, Chen $X$, Zhang $X$, Tang $Q$, Liu S, Yao $K$ (2017): Clinical evaluation of corneal changes after phacoemulsification in diabetic and non-diabetic cataract patients, a systematic review and meta-analysis. Scientific Reports, 7(1): 14128-32.

18. Gonzalez-Salinas R, Garza-Leon M, Saenz-de-Viteri M, Solis-S JC, Gulias-Cañizo R, Quiroz-Mercado H (2018): Comparison of cumulative dissipated energy delivered by active-fluidic pressure control phacoemulsification system versus gravity-fluidics. International Ophthalmology, 38(5): 1907-13.

19. Inoue $K$, Tokuda $Y$, Inoue $Y$, Amano S, Oshika T, Inoue J (2002): Corneal endothelial cell morphology in patients undergoing cataract surgery. Cornea, 21(4): 360-3.

20. Park J, Yum H, Kim MS, Harrison AR, Kim EC (2013): Comparison of phaco-chop, divide-and-conquer, and stop-and-chop phaco techniques in microincision coaxial cataract surgery. Journal of Cataract \& Refractive Surgery, 39(10): 1463-9.

21. Demircan S, Atas M, Koksal M, Pangal E, Yuvaci I (2014): Relationship between lens density measurements by pentacam Scheimpflug imaging and torsional phacoemulsification parameters. Guoji Yanke Zazhi (Int Eye Sci), 14: 1739-43. 